\title{
Analisis Kompetensi Guru PAUD dalam Membuat Media Video Pembelajaran
}

\author{
Bahran Taib $^{1 凶}$, Nurhamsa Mahmud1 \\ Pendidikan Guru Pendidikan Anak Usia Dini, Universitas Khairun Ternate, Indonesia( ${ }^{(1)}$ \\ DOI: $10.31004 /$ obsesi.v6i3.1842
}

\begin{abstract}
Abstrak
Salah satu dampak dari penyebaran Covid-19 bagi kebijakan pendidikan di Indonesia adalah diberlakukannya pembelajaran jarak jauh (PJJ) secara daring. Sehiungga guru PAUD dituntut untuk memiliki kempetensi membuat media pembelajaran daring yang menyenangkan bagi siswa agar tujuan pembelajaran yang diharapkan dapat tercapai, salah satunya adalah pembuatan video pembelajaran. Tujuan penelitian adalah untuk mengetahui sejauh mana kompetensi guru PAUD di Ternate Utara dalam membuat media video pembelajaran. Penelitian ini adalah deskriptif kualitatif yang dilaksanakan dari bulan Maret sampai Juni 2021. Subjek penelitian ini adalah 8 guru dan 4 kepala sekolah PAUD di Ternate Utara. Kompetensi guru dalam membuat media video pembelajaran masih rendah, guru yang bisa membuat media video pembelajaran hanya 6 orang $(28,58 \%)$ dari 21 guru, tetapi kualitas video pembelajaran yang dihasilkan masih belum sempurna karena guru merekamnya melalui HP dan tanpa editing. Guru juga belum bisa mengunggah video pembelajaran yang telah jadi ke portal belajar atau situs web seperti Youtube.
\end{abstract}

Kata Kunci: kompetensi; guru paud; video pembelajaran

\begin{abstract}
One of the impacts of the spread of Covid-19 for education policy in Indonesia is the implementation of online distance learning (PJJ). So that PAUD teachers are required to have the competence to create fun online learning media for students so that the expected learning objectives can be achieved, one of which is making learning videos. The purpose of the study was to determine the extent of the competence of PAUD teachers in North Ternate in making learning video media. This research is a qualitative descriptive conducted from March to June 2021. The subjects of this study were 8 teachers and 4 PAUD principals in North Ternate. The competence of teachers in making learning video media is still low, only 6 teachers $(28.58 \%)$ of the 21 teachers can make learning video media, but the quality of the resulting learning video is still not perfect because the teacher records it via cellphone and without editing. Teachers also cannot upload finished learning videos to learning portals or websites such as Youtube.
\end{abstract}

Keyword: competence; paud teacher; learning video

Copyright (c) 2021 Bahran Taib, Nurhamsa Mahmud

$\triangle$ Corresponding author :

Email Address : baharulfa@yahoo.co.id (Tabing Koto Tangah, Padang, Indonesia)

Received 4 May 2021, Accepted 22 October 2021, Published 30 October 2021 


\section{PENDAHULUAN}

Salah satu dampak dari penyebaran Covid-19 bagi kebijakan pendidikan di Indonesia adalah diberlakukannya pembelajaran jarak jauh (PJJ). Agar PJJ atau belajar dari rumah bisa berjalan denagn maksimal dan mempermudah guru dalam proses belajar mengajar maka guru harus mengikuti perkembangan zaman, memunculkan terobosan baru yang mulai memanfaatkan jaringan komputer dan internet dalam proses pembelajaran yang sering disebut sebagai e-learning atau pembelajaran elektronik. E-learning merupakan suatu pembelajaran yang dalam pelaksanaannya menggunakan media atau jasa bantuan perangkat elektronika berupa audio, video, perangkat komputer ataupun kombinasi ketiganya (Munir, 2013). Dari istilah E-learning kemudian berkembang lagi menjadi pembelajaran daring (online learning). Menurut Thome pembelajaran daring merupakan pembelajaran yang memanfaatkan teknologi multimedia, video, kelas virtual, teks online animasi, pesan suara, email, telepon konferensi, dan video steraming online (Kuntarto, 2017). Pembelajaran daring dapat diartikan sebagai suatu pembelajaran yang dalam pelaksanaannya menggunakan jaringan internet, intranet dan ekstranet atau komputer yang terhubung langsung dan cakupannya global (luas).

Dengan adanya perubahan pembelajaran dari yang tatap muka berubah menjadi pembelajaran daring tentunya tidak mudah bagi jenjang PAUD. Dalam pembelajaran guru PAUD dituntut untuk harus bisa memanfaatkan teknologi dan internet untuk meningkatkan kinerja dan aktivitas peserta didik dikehidupan sehari-hari. Guru melakukan persiapan dimulai dari rencana pembelajaran, mengkomunikasikan dengan orang tua, dan fasilitas pendukung lainnya (Ayuni et al., 2020). Hal ini sesuai dengan yang diharapkan dalam pendidikan era revolusi industri 4.0 yakni generasi melek internet dan teknologi. Salah satu media pembelajaran dengan memanfaatkan teknologi dalam pembelajaran daring di PAUD adalah video pembelajaran. Video merupakah satu satu media pembelajaran audio visual. Melalui media ini anak-anak akan ditampilkan animasi, gambar, dan audio visual yang akan sangat membantu anak dalam fokus belajar guru juga lebih percaya diri dalam menyampaikan informasi. Sehingga guru dituntut untuk memiliki kompetensi dalam membuat video pembelajaran yang menyenangkan bagi siswa agar apa yang menjadi tujuan pembelajaran yang diharapkan dapat tercapai.

Berdasarkan hasil wawancara peneliti dibeberpa sekolah PAUD di Ternate Utara (PAUD Pembina 1, PAUD Pembina 3, PAUD Pembina 7 dan PAUD Pembina 8) selama 2 minggu mulai tanggal 01 Maret 2021 sampai 14 Maret 2021, selama pembelajaran daring guru lebih banyak memanfaatkan aplikasi WahatsApp untuk memberikan penugasan kepada siswa dengan cara memfoto tugas atau mengirim video pembelajaran yang diunduh dari Youtube, bukan video pembelajaran hasil karya guru yang bersangkutan. Guru memilih platform tersebut dengan beberapa alasan pertama sudah familiar digunakan banyak orang, dari segi signal mendukung untuk menjalan aplikasi WhatsApp, dilengkapi dengan vitur gambar, video call, voice note dan dapat membuat grup dalam sebuah obrolan (Pudyastuti \& Budiningsih, 2021). Padahal tuntutan Guru PAUD pada saat ini harus memiliki empat kompetensi dasar yaitu profesionalisme, pedagogik, kepribadian dan social. Salah satu kompetensi guru dalam pedagogik, yaitu kemampuan memanfaatkan teknologi informasi dan komunikasi untuk meningkatkan kualitas kegiatan pengembangan yang mendidik dan kompetensi professional, yaitu kemampuan memanfaatkan teknologi informasi dan komunikasi untuk pengembangan diri. Yunita, juga menuliskan bahwa salah satu indikator seorang guru harus profesional dan kompeten yaitu seorang guru harus mampu beradaptasi dengan suatu perkembangan keilmuan yang hari demi hari semakin canggih dengan cara penguasaan Teknologi Informasi dan Komunikasi (TIK) (Rohita, 2020). Salah satunya adalah guru harus memiliki kemampuan media video pembelajaran.

Peran video pembelajaran pada pembelajaran daring sangat penting sekali karena dapat menggantikan peran guru dalam menyampaikan materi sesuai Kompetensi Dasar yang sudah disesuaikan di masa pandemi dan dapat pula mengevaluasi pembelajaran, sehingga 
hambatan ruang dapat teratasi. Video mampu merangkum banyak kejadian dalam waktu yang lama menjadi lebih singkat dan jelas dengan disertai gambar dan suara yang dapat diulang-ulang dalam proses penggunaannya (Gusliati et al., 2019). Dengan demikian tujuan pembelajaran tetap tercapai dengan baik dan pembelajaran daring tetap berlangsung secara efektif (Arief, 2020). Diperlukan analisisi kompetensi Guru PAUD dalam membuat video pembelajaran untuk mengetahui sejauh manah guru PAUD bisa membuat video yang menarik, menyenangkan, dan tidak membosankan dalam pembelajaran daring dan apa yang menjadi kesulitan guru PAUD di Ternate dalam membuat media video pembelajaran.

Beberapa penelitian-penelitian lain yang pernah dialukuan dan menggunakan video pembelajaran untuk PAUD anatar lain Peningkatan Kompetensi Pedagogik Guru PAUD dalam Pembuatan Video Pembelajaran Sains Berbasis Smartphone (Shofiyah et al., 2021); Analisis Swot Video Pembelajaran "Menjadi Guru Paud Inovatif" Terhadap Kompetensi Pedagogik Guru di TK Nabila Yayasan Medina Semarang (Chodijah, 2016); The Effect of Animation Video Learning Media on Social Emotional Development of Early Children: A Literatute Review (Dhida, 2021); dan Penerapan Video Pembelajaran Anak Usia Dini pada Masa Pandemi Covid-19 (Supriyanto Elfa Wahyu; Safriyani, Rizka, 2021). Media pembelajaran yang memanfaatkan kemajuan tekhnologi untuk AUD adalah video pembelajaran, sehingga guru dituntut untuk memiliki kompetensi dalam membuat video pembelajaran yang interaktif, menarik dan menyengkan untuk AUD.

\section{METODOLOGI}

Metode penelitian yang digunakan adalah metode kualitatif, metode penelitian yang berlandaskan filsafat postpositivisme yang biasa digunakan untuk meneliti kondisi objek yang alamiah, di mana peneliti berperan sebagai instrumen kunci dan melakukan melukiskan suatu keadaan secara objektif atau berdasarkan fakta-fakta yang tampak (Sugiyono, 2018). Jenis penelitian kualitatif yang digunakan pada penelitian ini adalah deskriptif. Penelitian deskriptif bertujuan untuk mendiskripsikan suatu populasi, situasi, atau fenomena secara akurat dan sistematis. Metode pendekatan Deskriptif Kualitatif adalah metode pengolahan data dengan cara menganalisa faktor- faktor yang berkaitan dengan objek penelitian dengan penyajian data secara lebih mendalam terhadap objek penelitian. Metode pendekatan Deskriptif Kualitatif memudahkan penulis untuk mengungkap kenyataan di lapangan mengenai sejauh mana kompentensi guru PAUD di Ternate Utara dalam membuat video pembelajaran secara mendalam, sehinggap pada akhirnya diperoleh temuan penelitian yang akurat.

Penelitian dilakukan di PAUD yang letaknya di bagian Utara Kota Ternate. Terdapat 4 PAUD yang dijadikan tempat penelitian, yaitu: PAUD Pembina 1 beralamat di Kel.DufaDufa, PAUD Pembina 3 beralamat di Kel.Tabam, PAUD Pembina 7 beralamat di Kel.Tubo dan PAUD Pembina 8 beralamat di Kel. Koloncucu. Dalam penelitian ini, waktu yang dibutuhkan peneliti adalah tiga bulan, yaitu sejak bulan Maret hingga bulan Juni tahun 2021. Subjek dari penelitian ini adalah Pendidik(guru) dan kepala sekolah PAUD di Ternate Utara yang berasal dari 4 sekolah yang berbeda.

Informan dalam penelitian ini menggunakan teknik purposive sampling, yaitu teknik penentuan informan berdasarkan kriteria atau pertimbangan tertentu. Pemilihan informan dalam penelitian ini berdasarkan kriteria yang pertama adalah informan harus guru kelas A dan guru kelas B yang mengajar PAUD di Ternate Utara, memiliki pendidikan Strata satu Pendidikan AUD. Wawancara penelitian dilakukan tanpa paksaan dengan cara guru harus menyatakan bersedia menjadi informan. Peneliti menambahkan kepala sekolah di 4 sekolah PAUD di Ternate Utara sebagai informan pendukung dalam penelitian ini.

Penelitian ini peneliti menggunakan beberapa teknik pengumpulan data yaitu; 1 ) Wawancara, dimana penulis mewawancarai 8 guru dari 4 sekolah PAUD di Ternate Utara dimana setiap sekolah 2 guru yang diwawancari yaitu 1 guru kelas A dan 1 guru kelas B. Selain guru, penulis juga mewawancarai 4 kepala sekolah PAUD di Ternate Utara. 2) 
Observasi, observasi yang dilakukan berupa pengamatan dan pemeriksaan dokumen pendukung lainnya. Penulis mengamati media pembelajaran yang digunakan guru selama pembelajaran daring dan mengamati video pembelajaran yang dibuat oleh guru untuk mengetahui kualitas video pembelajaran yang telah dibuat. 3) Studi dokumentasi, dalam penelitian ini diperlukan untuk mempertajam analisis penelitian yang berkaitan dengan kompetensi guru PAUD dalam membuat media video pembelajaran. Data yang telah terkumpul diolah dan pengolahan data dilakukan dengan reduksi data, penyajian data, dan penarikan kesimpulan. Pada tahap reduksi data, peneliti memfokuskan pada kompetensi guru PAUD dalam membuat video pembelajaran. Penyajian data dilakukan setelah data direduksi, langkah selanjutnya data disajikan dalam bentuk teks yang bersifat naratif. Data dikelompokkan sesuai dengan sub bab masing-masing. Selanjutnya dilakukan penarikan kesimpulan yang dilakukan setelah menjabarkan berbagai data yang telah diperoleh yang merupakan hasil dari suatu penelitian.

Analisis data dimulai dengan melakukan wawancara mendalam dengan informan. Selanjutnya peneliti membuat transkip hasil wawancara dengan cara memutar kembali rekaman wawancara kemudian menuliskan kata-kata yang sesuai dengan apa yang ada direkaman tersebut. Tahap berikutnya peneliti membuat reduksi data dengan cara abstraksi, yaitu mengambil data yang sesuai dengan konteks penelitian dan mengabaikan data yang tidak diperlukan. Penelitian kualitatif harus memiliki kredibilitas sehingga dapat dipertanggung jawabkan, antara lain: a) Perpanjangan pengamatan Peneliti kembali ke lapangan untuk melakukan pengamatan untuk mengetahui kebenaran data yang diperoleh maupun menemukan data baru. b) Meningkatkan ketekunan Melakukan pengamatan secara lebih cermat. Dengan meningkatakan ketekunan, peneliti dapat melakukan pengecekan kembali apakah data yang ditemukan benar atau salah. c) Triangulasi Pengecekan data sebagai sebagai sumber dengan berbagai cara dan berbagai waktu. d) Analisis kasus negatif Peneliti mencari data yang berbeda dengan data yang ditemukan. Apabila tidak ada data yang berbeda maka data yang ditemukan sudah dapat dipercaya. e) Menggunakan bahan referensi Bahan referensi yang dimaksud adalah sebagai pendukung data yang ditemukan, sebagai contoh data hasil wawancara perlu didukung adanya rekaman wawancara. f) Menggunakan member check. Mengadakan kesepakatan dengan informan bahwa data yang telah diterima sudah sesuai dengan hasil wawancara. Apabila data sudah benar maka data sudah dianggap valid, maka peneliti perlu melakukan diskusi dengan pemberi data agar penafsiran akan data yang diperoleh dapat disepakati.

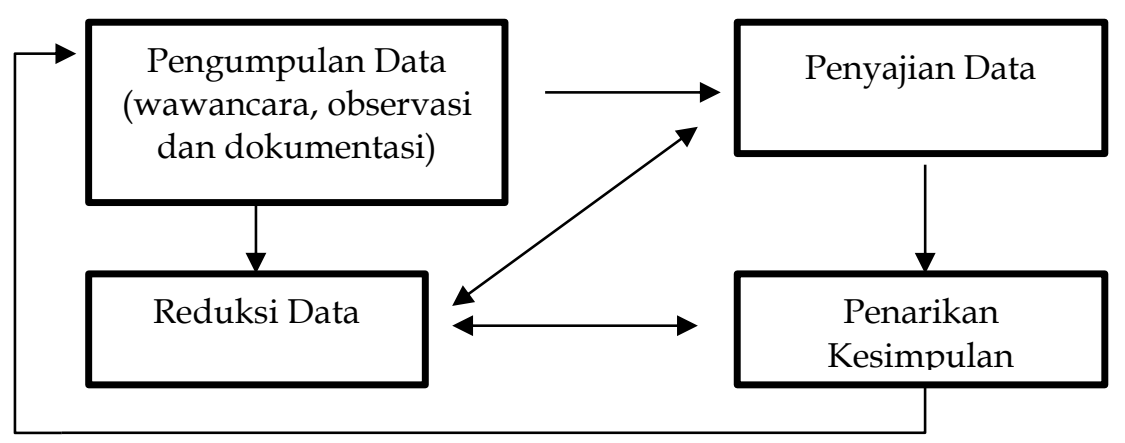

Bagan 1. Alur Penelitian Kualitatif

\section{HASIL DAN PEMBAHASAN}

Kompetensi guru adalah hasil dari penggabungan dari kemampuan-kemampuan yang banyak jenisnya, dapat berupa seperangkat pengetahuan, keterampilan, dan perilaku yang harus dimiliki, dihayati, dan dikuasai oleh guru dalam menjalankan tugas keprofesionalannya. 
Salah satu kompetensi yang harus dimiliki guru adalah kompetensi pedagogik, yaitu kemampuan memanfaatkan teknologi informasi dan komunikasi untuk meningkatkan kualitas kegiatan pengembangan yang mendidik dan kompetensi professional, yaitu kemampuan memanfaatkan teknologi informasi dan komunikasi untuk pengembangan diri. Yunita, juga menuliskan bahwa salah satu indikator seorang guru harus profesional dan kompeten yaitu seorang guru harus mampu beradaptasi dengan suatu perkembangan keilmuan yang hari demi hari semakin canggih dengan cara penguasaan Teknologi Informasi dan Komunikasi (TIK) (Rohita, 2020). Salah satu kemapuan yang harus dimiliki oleh guru adalah kemampuan membuat media video pembelajaran. Dengan media ini pembelajaran daring dapat dilaksanakan lebihe efektif (Fauziddin et al., 2021)

Berdasarkan hasil wawancara guru PAUD di empat sekolah PAUD Kota Ternate Utara (PAUD Pembina 1, PAUD Pembina 7 dan PAUD Pembina 8, selama pembelajaran daring guru lebih sering menggunakan aplikasi WhatsApp. Sedangkan untuk guru PAUD Pembina 3 lebih memilih Luring dengan cara mendatangi siswanya ke rumah-rumah.

Penggunaan aplikasi WhatshApp dalam pembelajaran daring dianggap lebih mudah pengoperasinya daripada aplikasi pembelajaran daring lainnya serta lebih familiar bagi masyarakat terutama wali murid. Menurut Ibu Yuni,Guru PAUD Pembina 7 "Selama pembelajaran daring saya menggunakan WhatshApp karena lebih mudah mengoperasikannya dan orang tua juga banyak yang mempunyai aplikasi ini". Lebih lanjut ibu Yuni juga mengatakan "ketika pembelajaran daring, materi dan tugas dikirim melalui WhatshApp dalam bentuk foto atau gambar, kalaupun berupa video pembelajaran biasanya diambil dari youtube. Tidak membuat video pembelajaran sendiri" (wawancara tanggal 03 April 2021 di Sekolah PAUD Pembina 7, Kel. Tubo).

Salah satu syarat utama untuk bisa membuat video pembelajaran, salah satunya adalah seorang guru dituntut harus memiliki keterampilan dalam pengoperasian komputer. Berikut ini adalah data hasil wawancara jumlah guru PAUD di Kota Ternate Utara yang memiliki keterampilan dalam pengoperasian komputer.

Tabel 1. Keterampilan Komputer Guru PAUD

\begin{tabular}{ccccccc}
\hline No & Nama Sekolah & \multicolumn{6}{c}{ Keterampilan Kompuer Guru (Orang) } & Jumlah \\
& & Kurang & Cukup & Bisa & Mahir & \\
\hline 1 & PAUD Pembina 1 & 2 & 3 & 3 & 0 & 8 \\
2 & PAUD Pembina 3 & 2 & 2 & 0 & 0 & 4 \\
3 & PAUD Pembina 7 & 1 & 2 & 2 & 0 & 5 \\
4 & PAUD Pembina 8 & 1 & 2 & 1 & 0 & 4 \\
\hline \multicolumn{2}{c}{ Total } & 6 & 9 & 6 & 0 & 21 \\
\hline
\end{tabular}

Sumber: wawancara guru yang dilaksanakan pada tanggal 15, 17, 18, dan 22 Maret 2021

Berdasarkan tabel 1, keterampilan komputer guru PAUD yang berada pada kategori kurang berjumlah 6 orang atau 28.57\% dimana guru tersebut masih memerlukan bantuan teman dalam mengoperasikan komputer. Guru dengan keterampilan komputer yang berada pada kategori cukup berjumlah 9 orang atau 42,86\% dimana guru sudah bisa program komputer word, excel dan power point meskipun tampilanya masih sederhana. Guru dengan keterampilan komputer yang berada pada kategori bisa berjumlah 6 orang atau 28,57\% dimana guru sudah bisa program komputer word, excel dan power point dengan tampilannya yang sudah cukup menarik. Guru dengan keterampilan komputer yang berada pada kategori mahir belum ada, guru dikatakan mahir apabila guru tidak hanya bisa program word, excel dan power point saja tetapi bisa program komputer lainnya. Data tersebut menunjukkan bahwa keterampilan guru PAUD di Ternate Utara masih rendah.

Dalam membuat video pembelajaran tentunya guru memerlukan alat bantu komputer. Komputer digunakan untuk proses editing video dan produksi video. Disarankan menggunakan komputer yang mempunyai processor, VGA, dan kapasitas memory yang 
mumpuni. Sedangkan kebutuhan software antara lain software untuk proses editing dan produksi video, misalnya Camtasia. Software untuk presentasi, misalnya Ms. PowerPoint dan software untuk membuat animasi pembelajaran misalnya videoscribe. Jika guru tidak memiliki keterampilan computer tentu saja berpengaruh terhadap kompetensi guru dalam membuat video pembelajaran yang baik dan berkualitas. Berdasarkan hasil wawancara peneliti dengan ke kepala sekolah di PAUD Ternate Utara diperoleh data jumlah guru PAUD yang memiliki kompetensi dalam membuat video pembelajaran.

Tabel 2. Kompetensi Guru PAUD dalam Membuat Video

\begin{tabular}{llllc}
\hline No & Nama Sekolah & $\begin{array}{l}\text { Jumlah Guru yang Bisa } \\
\text { Membuat Video } \\
\text { Pembelajaran }\end{array}$ & $\begin{array}{l}\text { Jumlah Guru yang Belum } \\
\text { Bisa Membuat Video } \\
\text { Pembelajaran }\end{array}$ & Jumlah \\
\hline 1 & PAUD Pembina 1 & 4 & 4 & 8 \\
2 & PAUD Pembina 3 & 0 & 4 & 4 \\
3 & PAUD Pembina 7 & 1 & 4 & 5 \\
4 & PAUD Pembina 8 & 1 & 3 & 4 \\
\hline \multicolumn{7}{l}{ Total } & 6 & 15 & 21 \\
\hline \multicolumn{7}{r}{ Sumber: wawancara kepala sekolah PAUD pada tanggal 15, 17, 18, dan 22 Maret 2021 }
\end{tabular}

Berdasarkan tabel 2, diketahui bahwa dari ke empat sekolah PAUD di Kota Ternate Utara, 6 guru atau 28,58\% yang sudah bisa membuat video pembelajaran dan 15 guru atau $71,43 \%$ yang belum bisa membuat video pembelajaran dari 21 guru. Dari ke empat sekolah PAUD, PAUD Pembina 3 tidak ada guru yang bisa membuat video pembelajaran. Data tersebut menunjukkan rendahnya kompetensi guru dalam membuat media video pembelajaran.

Pemanfaatan video pembelajaran sebagai media pembelajaran sangat bagus diterapkan pada pembelajaran daring sehingga guru harus bisa membuat video pembelajaran sendiri yang disesuaikan dengan karakteristik peserta didiknya. Berdasarkan hasil penelitian Berdasarkan hasil penelitian dengan judul Penerapan Video Pembelajaran Darng Anak Usia Dini Pada Masa Pandemi Covid-19 (Syafi'i dkk., 2020) menyatakan bahwa video pembelajaran sebagai media pembelajaran daring dinilai cukup menyita perhatian anak dalam belajar dari ruma, sehingga anak-anak tertarik atau munculnya motivasi belajar karena video pembelajaran menampilkan ibu guru. Namun, ada beberapa kendala atau kesulitan yang dihadapi oleh guru PAUD di Ternate Utara dalam membuat video pembelajran sendiri.

Berdasarkan hasil wawancara kepala sekolah dari masing-masing sekolah PAUD di Ternate Utara, kendala atau kesulitan yang dihadapi guru dalam membuat video pembelajaran dapat dilihat pada pada tabel 3.

Ketika membuat media video pembelajaran tentunya seorang guru harus mengetahui apa yang menjadi karakteristik yang harus dipenuhi dalam membuat video pembelajaran. Berdasarkan hasil wawancara guru PAUD tentang karakteristik media video pembelajaran, semua guru memiliki pendapat yang sama, video pembelajaran harus menggunakan bahasa yang sederhana yang mudah dimengerti, bahasa yang umum bersifat membantu peserta didik agar mudah memahami isi materi yang disampaikan melalui video pembelajaran tersebut.

Menurut ibu Irna (guru kelas B di PAUD Pembina 3), "media video pembeljaran menggunakan bahasa yang sederhana, mudah dimengerti, dan menggunakan bahasa yang umum" (wawancata tanggal 07 April 2021 di Sekolah PAUD Pembina 3, Kel. Tabam). Pendapat serupa juga diasampaikan Ibu Nona (guru kelas B di sekolah PAUD Pembina 8), "karakteristik media video pembelajaran yaitu menggunakan bahasa yang sederhana dan yang mudah dimengerti, menggunakan bahasa yang umum yang bersifat membantu dalam respon kegiatan" (wawncara tanggal 09 April 2021 di sekolah PAUD Pembina 8, Kel. Koloncucu). 


\section{Tabel 3 Kendala Guru PAUD dalam Membuat Video Pembelajaran}

\begin{tabular}{|c|c|c|}
\hline No & Asal Sekolah & Kendala \\
\hline 1 & PAUD Pembina 1 & $\begin{array}{l}\text { 1. Guru belum pernah mengikuti pelatihan video pem belajaran. } \\
\text { 2. Sekolah belum pernah mengadakan pelatihan pembuatan video } \\
\text { pembelajaran karena keterbatasan sarana dan dana. }\end{array}$ \\
\hline 2 & PAUD Pembina 3 & $\begin{array}{l}\text { 1. Guru belum menguasai komputer. } \\
\text { 2. Guru belum pernah mengikuti pelatihan video pem belajaran. } \\
\text { 3. Sekolah belum pernah mengikuti pelatihan pembuatan video } \\
\text { pembelajaran }\end{array}$ \\
\hline 3 & PAUD Pembina 7 & $\begin{array}{l}\text { 1. Kurangnya pengetahuan dan penguasaan terkait video pembelajaran } \\
\text { serta belum adanya kesiapan dan keterampiulan guru. } \\
\text { 2. Guru belum pernah mengikuti pelatihan video pem belajaran. } \\
\text { 3. Sekolah belum pernah mengadakan pelatihan pembuatan video } \\
\text { pembelajaran karena sebagian guru tidak memiliki laptop. } \\
\text { 4. Masih minimnya keinginan guru untuk belajar membuat video } \\
\text { pembelajaran. }\end{array}$ \\
\hline 4 & PAUD Pembina 8 & $\begin{array}{l}\text { 1. Guru belum pernah mengikuti pelatihan video pem belajaran. } \\
\text { 2. Sekolah belum pernah mengadakan pelatihan pembuatan video } \\
\text { pembelajaran karena keterbatasan sarana dan dana }\end{array}$ \\
\hline
\end{tabular}

Sumber: wawancara kepala sekolah PAUD pada tanggal 15, 17, 18, dan 22 Maret 2021

Berdasarkan pendapat responden, maka bisa disimpulkan karakteristik media video pembelajaran adalah bahasa. Selain bahasa, ada beberapa karakteristik dalam membuat video pembelajaran menurut Riyana, yaitu: Clarity of Massage (kejalasan pesan), Stand Alone (berdiri sendiri), User Friendly (bersahabat/akrab dengan pemakainya), Representasi Isi, Visualisasi dengan media, Menggunakan kualitas resolusi yang tinggi, dan Dapat digunakan secara klasikal atau individual.

Berdasarkan hasil wawancara guru PAUD untuk mengetahui sejauhmana guru mngetahui langkah-langkah dalam membuat media video pembelajaran, menurut ibu Fitria (guru PAUD Pembina 7), " pertama menyiapkan alat/bahan (peraga) yang dibutuhkan, kedua melakukan rekaman dan ketiga editing video". Menurut ibu Hasna (guru PAUD Pembina 3), "Ada 3 langkah utama dalam membuat video pembelajaran yaitu menulis naskah, melakukan rekaman, dan editing video" (wawancata tanggal 07 April 2021 di Sekolah PAUD Pembina 3, Kel. Tabam). Pendapat lain diungkapkan ibu Saeni (guru kelas A di PAUD Pembina 8), "menulis naskah, menyiapkan media pembelajaran, lalu mulai merekam dan acting di depan kamera" (wawncara tanggal 09 April 2021 di sekolah PAUD Pembina 8, Kel. Koloncucu).

Berdasarkan hasil wawancara, maka peneliti dapat menyimpulkan bahwa guru belum memahami secara keseluruhan langkah-langkah dalam membuat video pembelajaran. Menurut Christopher (Ramadayanti, 2020) menyebutkan beberapa poin terkait proses produksi video pembelajaran, pertama yaitu menyiapkan materi, merangkum bahan dan membuat menjadi naskah; kedua produksi yaitu menggunakan media perekam (handphone), pencahayaan yang sesuai, pastikan video dan audia terekam dengan baik; dan terakhir pasca produksi yaitu melakukan review dan editing. Bila videonya sudah jadi, langkah terakhir yang harus Bapak/Ibu Guru lakukan ialah mengunggahnya ke portal belajar atau situs web seperti Youtube. Daftarkan diri terlebih dulu di portal belajar atau situs web terkait, lalu pilih unggah video. Bila proses mengunggah sudah berhasil, maka Bapak/Ibu Guru bisa membagikan URL video pembelajaran tersebut pada para siswa (Serenata, 2020).

Agar peneliti mengetahui sejauh mana keompetensi guru PAUD di Ternate Utaara dalam membuat media video pembelajan, selain melakukan wancara terhadap guru peneliti melakukan obeservasi produk video pembelajaran yang dihasilkan oleh salah satu guru PAUD di Ternate oleh Ibu Sofia (guru kelompok A PAUD Pembina 1) dengan tema Negaraku dengan sub tema Lambang Negara. 


\section{Aspek Format}

Jika dilihat dari aspek format video pemebelajaran yang buat masih berkategori kurang karena belum terdapat gambar atau animasi pada media, belum ada musik pengiringnya, dan belum ada pemilihan huruf dan warna teks. Untuk lebih jelasnya perhatikan gambar 1.
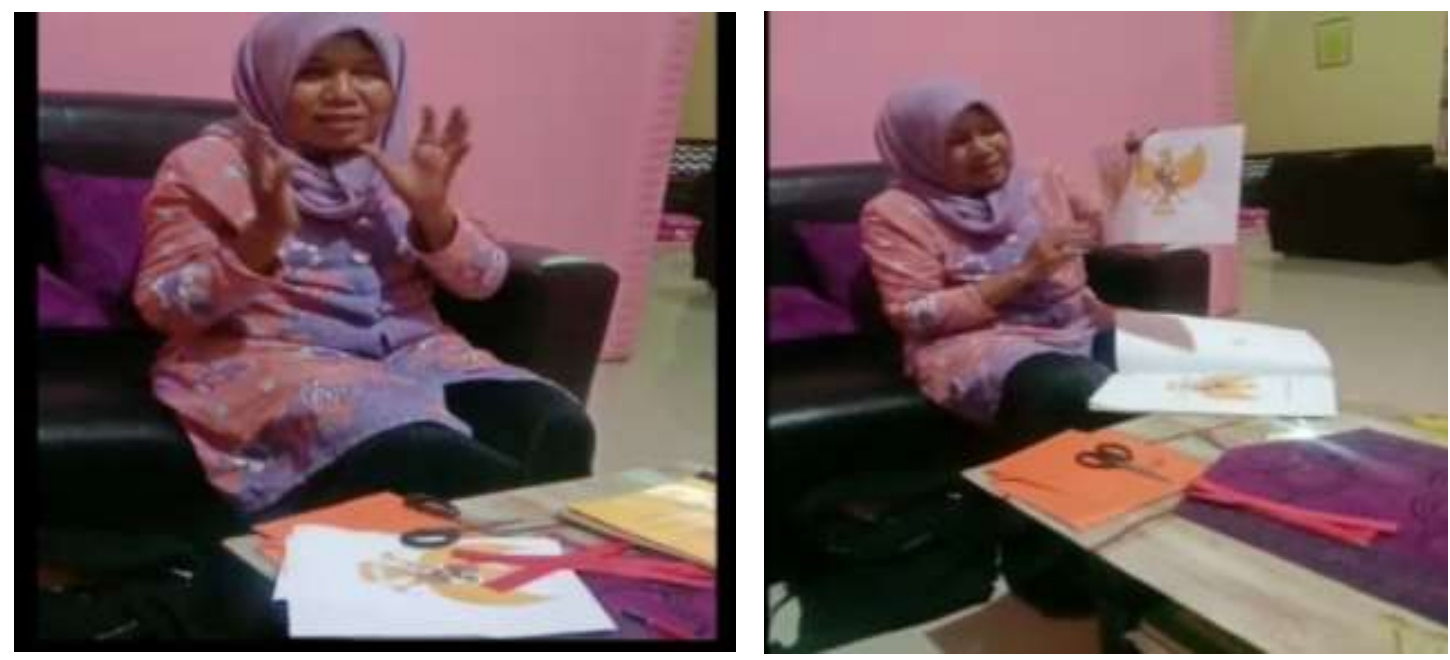

Gambar 1. Video Pembelajaran Ibu Sofia

Berdasarkan gambar 1, dapat dilihat bahwa format video pembelajarannya masih sederhana sekali, hanya direkam dengan HP tanpa adanya pengeditan. Dari segi pecahayaannyapun masih sangat kurang. Dalam pembuatan media video pembelajaran, format video pembelajaran yang menarik dan kreatif diperlukan agar menghasilkan video pembelajaran yang menarik agar peserta didik lebih semangat dalam belajar dan tidak mudah bosan.

\section{Aspek Isi}

Jika dilihat dari aspek isi video pembelajarannya yang dibuat, kejelasan konsep yang disampaikan dan urutan penyajian materi sudah cukup baik meskipun cara penyampaiannya kurang menarik. Ketika guru memberikan tugas untuk menganyam pohon beringin, guru hanya memberikan penjelasan langkah-langkahnya dan menunjuk hasil yang sudah jadi tanpa mempraktekkan langsung. Selain itu, tujuan pembelajaran tidak disampaikan, guru hanya menyampaikan tema dan sub tema pembelajarannya saja. Penyampaian tujuan pembelajaran diawal pembelajaran sangat penting sekali agar guru bisa mengetahui capaian apa saja yang diharapkan dari peserta didik setelah menjalani proses pembelajaran.

\section{Aspek Bahasa}

Jika dilihat dari aspek bahasa, bahasa yang digunakan sudah cukup baku, tidak bertele-tele tetapi karena perekamannya melalui hp dan direkam pada tempat yang tidak mendukung maka audio atau suara yang dihasilkan dalam perekaman kurang jelas, dan ribut. Aspek bahasa dalam membuat media video pembelajaran tentunya sangat penting sekali karena penyampaian materi dengan bahasa yang menarik dan mudah dipahami tentunya membuat peserta didik lebih cepat memahami materi yang disampaikan guru dan kualitas audio yang baik tentunya juga diperlukan sekali agar peserta didik bisa mendengar penyampain materi dengan baik dan jelas.

\section{Pembahasan}

Menurut Undang-Undang Republik Indonesia Nomor 14 Tahun 2005 Tentang Guru dan Dosen menyatakan bahwa kompetensi adalah seperangkat pengetahuan, keterampilan, 
dan perilaku yang harus dimiliki, dihayati, dan dikuasai oleh guru atau dosen dalam melaksanakan tugas keprofesionalan. Menurut Finch \& Crunkilton, menyatakan "Kompetencies are those taks, skills, attitudes, values, and appreciation thet are deemed critical to successful employment" (Amarulloh, 2021). Pernyataan ini mengandung makna bahwa kompetensi meliputi tugas, keterampilan, sikap, nilai, apresiasi diberikan dalam rangka keberhasilan hidup/penghasilan hidup. Kompetensi guru adalah hasil dari penggabungan dari kemampuan-kemampuan yang banyak jenisnya, dapat berupa seperangkat pengetahuan, keterampilan, dan perilaku yang harus dimiliki, dihayati, dan dikuasai oleh guru dalam menjalankan tugas keprofesionalannya.

Salah satu kompetensi yang harus dimiliki guru PAUD adalah harus bisa memanfaatkan teknologi informasi dan komunikasi dalam mendesain inovasi pembelajaran di era digital, yakni harus berbasis pada TPACK dan HOTS dengan mampu membuat video pembelajaran yang sesuai dengan prinsip pembelajaran bagi anak usia dini yaitu belajar sambil bermain. Sehingga dalam pembuatan video pembelajaran untuk anak usia dini harus yang menyenangkan agar anak tidak malas atau cepat bosan dalam belajar.

Hasil penelitian menunjukkan bahwa kompetensi guru PAUD di Ternate Utara di PAUD Pembina 1, PAUD Pembina 3, PAUD Pembina 7 dan PAUD Pembina 8 dalam membuat media video pembelajaran masih rendah. Hal ini dapat dilihat hanya 6 guru atau $28,58 \%$ yang sudah bisa membuat video pembelajaran dan 15 guru atau $71,43 \%$ yang belum bisa membuat video pembelajaran dari 21 guru. Dari ke empat sekolah PAUD, PAUD Pembina 3 tidak ada guru yang bisa membuat video pembelajaran.

Kualtas produk video pembelajaran yang dihasilkan oleh 6 guru PAUD di Ternate Utara belum bisa dikatakan sempurna karena jika dilihat dari aspek format video pembelajaran belum terdapat gambar atau animasi pada media, belum ada musik pengiringnya, dan belum ada pemilihan huruf dan warna teks. Format video pembelajaran yang dibuat masih sederhana sekali, hanya direkam dengan HP tanpa adanya pengeditan sehingga audio atau suara yang dihasilkan kualitasnya juga kurang bagus dan pencahayaanyapun kurang bagus. Dalam pembuatan media video pembelajaran untuk anak usia dini harus yang menyenangkan agar anak tidak malas atau cepat bosan dalam belajar sehingga format video pembelajarannya harus dibuat menarik dan kreatif.

Untuk membuat video pembelajaran yang menarik bagi AUD, video pembelajaran haru memiliki unsur-unsur yaitu; 1) Teks, teks terdiri dari unit-unit bahasa dalam penggunaannya. Unit-unit bahasa tersebut adalah merupakan unit gramatikal seperti klausa atau kalimat namun tidak pula didefenisikan berdasarkan ukuran panjang kalimatnya. Teks terkadang pula digambarkan sebagai sejenis kalimat yang super yaitu sebuah unit gramatikal yang lebih panjang dari pada sebuah kalimat yang saling berhubungan satu sama lain. Jadi sebuah teks terdiri dari beberapa kalimat sehingga hal itulah yang membedakannya dengan pengertian kalimat tunggal. Selain itu sebuah teks dianggap sebagai unit semantik yaitu unit bahasa yang berhubungan dengan bentuk maknanya. Dengan demikian teks itu dalam realisasinya berhubungan dengan klausa yaitu satuan bahasa yang terdiri atas subjek dan predikat dan apabila diberi intonasi final akan menjadi sebuah kalimat. 2) Gambar (Image), gambar dapat meringkas dan menyajikan data kompleks dengan cara yang baru dan lebih berguna. Sering dikatakan bahwa sebuah gambar mampu menyampaikan seribu kata tapi, itu hanya berlaku ketika kita bisa menampilkan gambar yang diinginkan saat kita memerlukannya. Gambar juga bisa berfungsi sebagai ikon, yang bila dipadu dengan teks, menunjukkan berbagai opsi yang bisa dipilih (select) atau gambar bisa munculfullscreenmenggantikan teks, tapi tetap memiliki bagian-bagian tertentu yang berfungsi sebagai pemicu yang bila diklik akan menampilkan objek atau event multimedia lain. 3) Suara (Audio), pengertian suara (audio) menurut Suyanto (2006) adalah sesuatu yang disebabkan perubahan tekanan udara yang menjangkau gendang telinga manusia. Audio terdiri dari beberapa jenis yaitu Waveform Audio, Format DAT, Format MIDI, Audio CD, MP3. 4) Animasi, pemakaian animasi dalam komputer telah dimulai dengan ditemukannya software 
komputer yang dapat digunakan dalam berbagai keperluan seperti melakukan ilustrasi di komputer, serta membuat perubahan antara gaambar satu ke gambar berikutnya sehingga dapat terbentuk satu gabungan yang utuh..

Dalam membuat video pembelajaran yang tidak boleh diabaikan oleh guru adalah kejelasan pesan yang ingin disampaikan oleh guru melalui video pembelajaran tersebut, sehingga melalui video siswa dapat memahami pesan pembelajaran secara lebih bermakna dan informasi dapat diterima secara utuh sehingga dengan sendirinya informasi akan tersimpan dalam memory jangka panjang dan bersifat retensi. Penggunaan bahasa dalam video pembelajaran juga perlu diperhatikan oleh guru, bahasa yang digunakan adalah bahasa yang sedehana dan umum sehingga siswa dapat memahami dengan mudah apa yang disampaikan guru dalam video tersebut.

Langkah-langkah yang perlu diperhatikan oleh guru ketika membuat video pembelajaran, yaitu: guru harus memepersiapkan scenario atau naskah sebagai pemandu ke mana arah pembicaraan guru ketika direkam nanti. Tulis ringkasan materi bahan ajar yang nantinya bisa dibacakan di depan kamera. Setelah itu dilakukan proses rekaman dengan menggunakan media perekam seperti handphone, pencahayaan yang sesuai, pastikan video dan audia terekam dengan baik. Ketika sudah merekam seluruh materi, langkah selanjutnya ialah memastikan video tersebut didukung oleh ilustrasi yang tepat. Misalnya saja tabel, diagram, animasi, gambar, atau data-data lain. Pastikan guru mencantumkan sumber saat memasukkan ilustrasi ini ke dalam video. Ketika rekaman video dan ilustrasi sudah terkumpul, saatnya meng-edit video pembelajaran. Ada banyak software yang bisa digunakan, misalnya saja Movie Maker dari Windows, Adobe Premiere, Corel Video Studio, dan lain-lain. Dalam proses pengeditan, guru dituntut untuk bisa berkreasi dan berpikir out of the box agar video pembelajaran bisa tetap seru, menyenangkan, dan tidak membuat jenuh siswa. Jika video dan ilustrasi sudah tergabung, silakan render video dalam format $\mathrm{mp} 4$ atau lainnya yang sesuai dengan ketentuan. Langkah terakhir apabila videonya sudah jadi ialah mengunggahnya ke portal belajar atau situs web seperti Youtube. Daftarkan diri terlebih dulu di portal belajar atau situs web terkait, lalu pilih unggah video. Bila proses mengunggah sudah berhasil, maka guru bisa membagikan URL video pembelajaran tersebut pada para siswa.

Media video pembelajaran dapat menjadi alternatif guru untuk membantu guru dalam pembelajaran daring di masa pandemi Covid-19 karena video pembelajaran dapat menggantikan peran guru dalam menjelaskan materi pembelajaran meskipun tidak bertatap muka langsung di depan kelas. Berdasarkan penelitian Ita Qurrata' Ayun, pembelajaran daring dengan video pembelajaran menunjukkan meningkatnya motivasi AUD dalam belajar (A'yun et al., 2015).

Oleh karena itu, penting sekali bagi seorang guru untuk memiliki kompetensi dalam membuat video pembelajaran karena akan membantu guru dalam pelaksanaan pembelajaran daring. Manfaat media pembelajaran video bagi guru PAUD yaitu 1) guru memahami bahwa meskipun pembelajaran dilakukan dari rumah, guru mampu membuat materi pembelajaran dengan pembahasannya yang lebih jelas dan menarik, 2) pembelajaran menjadi lebih menarik dan sesuai dengan kebutuhan anak karena visual dan audio disesuaikan dengan tema pembelajaran sehingga dapat meningkatkan kualitas hasil belajar anak, 3) guru menjadi lebih produktif dan bertindak positif dalam menghadapi pembelajaran daring di masa pandemi Covid-19 saat ini, 4) membangkitkan mood atau perasaan anak untuk lebih positif sehingga keadaan sosial emosional anak lebih terkontrol, 5) membangkitkan keaktifan dan keikutsertaan anak dalam pembelajaran karena anak akan merespon video animasi yang telah dilihatnya (Pratiwi, 2020).

Rendahnya kompetensi guru PAUD di Ternate Utara dalam membuat video pembelajaran menjadi tantangan bagi peneliti untuk bisa meningkatkan kompetensi pedagogik guru PAUD di Ternate Utara dengan melakukan pelatihan bagaimana cara membuat video pembelajaran yang baik dan berkualitas. 
Adapun yang menjadi kendala guru PAUD di Ternate Utara dalam membuat video pembelajaran, antara lain: 1) Masih rendahnya keterampilan guru dalam mengoperasikan komputer. Keterampilan komputer digunakan untuk proses editing video dan produksi video. Disarankan menggunakan komputer yang mempunyai processor, VGA, dan kapasitas memori yang mumpuni. Sedangkan kebutuhan software antara lain software untuk proses editing dan produksi video, misalnya Camtasia. Software untuk presentasi, misalnya Ms. PowerPoint dan software untuk membuat animasi pembelajaran misalnya video scribe. 2) Pengetahuan dan pemahaman guru tentang video pembelajaran masih kurang. Rata-rata guru belum memahami karakteristik video pembelajaran, unsur apa saja yang harus ada dalam video pembelajaran dan langkah-langkah apa saja yang perlu dipersiapkan dalam membuat video pembelajaran, dan 3) Motivasi guru untuk belajar membuat video pembelajaran masih rendah.

Rendahnya kompetensi guru PAUD di Ternate Utara dalam membuat video pembelajaran, berdasarkan hasil penelitian disebabkan oleh; 1) kesadaran guru masih rendah pada literasi digital, 2) kurangnya motivasi guru untuk meng-upgrade diri menjadi lebih canggih dan profesional, 3) Guru belum pernah mengikuti pelatihan pembuatan video pembelajaran, 4) sekolah belum pernah mengadakan pelatihan pembuatan video pembelajaran karena keterbatasan sarana dan dana, dan 5) kurang adanya perhatian dari dinas pendidikan. Dari dinas pendidikan belum pernah melakukan pelatihan video pembelajaran bagi guru-guru PAUD di Ternate Utara.

Kompetensi guru PAUD di Ternate Utara dalam membuat video pembelajaran yang rendah tentunya diperlukan perhatian dan dukungan dari dinas pendidikan dengan diadakanannya pelatihan pembuatan video pembelajaran. Harapanya melalui pelatihan membuat video pembelajaran dapat meningkatkan keterampilan dan mengembangkan kreativitas guru PAUD. Dengan kompetensi guru yang baik tentunya akan menghasilkan kualitas generasi penerus bangsa yang unggul.

\section{SIMPULAN}

Kompetensi guru PAUD di Ternate Utara dalam membuat media video pembelajaran masih rendah dengan kualitas video pembelajaran yang dihasilkan juga masih belum sempurna. Hal ini disebabkan kurangnya keterampilan guru dalam pembuatan video pembelajaran.. Guru belum pernah mengikuti pelatihan pembuatan video pembelajaran baik dari sekolah maupun dinas pendidikan yang belum pernah menyelenggarakan. Dengan demikian perlu adanya perhatian khusus dari dinas pendidan untuk menyelenggarakan pelatihan agar kompetensi guru PAUD dalam membuat video pembelajaran dapat ditingkatkan sehingga kualitas video pembelajaran yang dibuat lebih menarik dan disukai anak.

\section{UCAPAN TERIMA KASIH}

Ucapan terima kasih yang sedalam-dalamnya saya sampaikan kepada Prof.Dr.Husen Alting,SH,.MH (Rektor Unkhakir) dan Dr.Abdulrasyid Tolangara,M.Si (Dekan FKIP Unkhair) atas saran dan dukungannya dalam penelitian ini.

\section{DAFTAR PUSTAKA}

A'yun, Q., Prihartanti, N., \& Chusniatun. (2015). Peran Orangtua dalam Pendidikan Anak Usia Dini (Studi Kasus pada Keluarga Muslim Pelaksana Homeschooling). Jurnal Indigenous, 13(2), 33-40. https:// doi.org/10.23917/indigenous.v13i2.2601

Amarulloh, G. K. (2021). 4 Standar Kompetensi Guru Berdasarkan Undang Undang Lengkap https://www.gurupendidikan.co.id/kompetensi-guru/ 
Arief, B. (2020). Manfaat Membuat Video Pembelajaran. https:// perpustakaansman112.sch.id/2020/07/14/manfaat-membuat-videopembelajaran/

Ayuni, D., Marini, T., Fauziddin, M., \& Pahrul, Y. (2020). Kesiapan Guru TK Menghadapi Pembelajaran Daring Masa Pandemi Covid-19. Jurnal Obsesi : Jurnal Pendidikan Anak Usia Dini, 5(1), 414. https:/ / doi.org/10.31004/obsesi.v5i1.579

Chodijah, N. R. (2016). Analisis Swot Video Pembelajaran "Menjadi Guru Paud Inovatif" Terhadap Kompetensi Pedagogik Guru Di Tk Nabila Yayasan Medina Semarang. http://lib.unnes.ac.id/id/eprint/25600

Dhida, T. T. (2021). The Effect of Animation Video Learning Media on Social Emotional Development of Early Children: A Literature Review. Early Childhood Educational and Development Journal, 3(1), 47-58.

Fauziddin, M., Mayasari, D., \& Rizki, L. M. (2021). Effective Learning for Early Childhood during Global Pandemic. Al-Ishlah: Jurnal Pendidikan, 13(1). https:// doi.org/10.35445/alishlah.v13i1.458

Gusliati, P., Eliza, D., \& Hartati, S. (2019). Analisis Video Pembelajaran Share Book Reading Menggunakan Cerita Rakyat Sabai Nan Aluih pada Anak Usia Dini. Jurnal Obsesi : Jurnal Pendidikan Anak Usia Dini, 3(2), 320. https:// doi.org/10.31004/obsesi.v3i2.176

Kuntarto, E. (2017). Keefektifan Model Pembelajaran Daring Dalam Perkuliahan Bahasa Indonesia di Perguruan Tinggi. Indonesian Language Education and Literature, 3(1), 99-110.

Munir. (2013). Multimdia : Konsep dan Aplikasinya Dalam Pendidikan. Alpfabeta.

Pratiwi, H. (2020). Screen Time dalam Perilaku Pengasuhan Gererasi Alpha pada Masa Tanggap Darurat Covid-19. Jurnal Obsesi : Jurnal Pendidikan Anak Usia Dini, 5(1), 265. https:// doi.org/10.31004/obsesi.v5i1.544

Pudyastuti, A. T., \& Budiningsih, C. A. (2021). Efektivitas Pembelajaran E-Learning pada Guru PAUD Selama Pandemic Covid-19. Jurnal Obsesi: Jurnal Pendidikan Anak Usia Dini, 5(2), 1667-1675. https:/ / doi.org/10.31004/obsesi.v5i2.873

Ramadayanti, A. (2020). Membuat Video Pembelajaran Yang Menarik di Masa Pandemi Covid-19-BSI News. https://news.bsi.ac.id/membuat-video-pembelajaran-yangmenarik-di-masa-pandemi-covid-19/

Rohita, R. (2020). The Ability of Ece Teachers to Use ICT in The Industrial Revolution 4.0. Jurnal Obsesi: Jurnal Pendidikan Anak Usia Dini, 4(2), 502. https:// doi.org/10.31004/obsesi.v4i2.339

Serenata. (2020). Tutorial Dasar Membuat Video Pembelajaran. Quipper. https:// www.quipper.com/id/blog/tips-trick/tutorial-video-pembelajaran/

Shofiyah, N., Nisak Aulina, C., \& Efendi, N. (2021). Peningkatan Kompetensi Pedagogik Guru PAUD dalam Pembuatan Video Pembelajaran Sains Berbasis Smartphone. Murhum: Jurnal Pendidikan Anak Usia Dini, 23-33. https://doi.org/10.37985/murhum.v2i1.29

Supriyanto Elfa Wahyu; Safriyani, Rizka, C. W. (2021). Strategi Pembelajaran Daring Anak Usia Dini pada Masa Pandemi Covid-19. In Musamus Journal of Primary Education (Vol. 3, Issue Musamus Journal of Primary Education Vol 3 No 2 (April, 2021), pp. 145156). https:// ejournal.unmus.ac.id/index.php/primary/article/view/3227/1874

Suyanto, S. (2006). Pengenalan Sains Untuk Anak Tk Dengan Pendekatan "Open Inquiry." http://staff.uny.ac.id/sites/default/files/PENGENALAN SAINS UNTUK ANAK $\underline{\mathrm{TK}(1) \cdot \mathrm{pdf}}$ 